\title{
Comparison of Diagnosis-specific Survival Scores for Patients With Cerebral Metastases from Malignant Melanoma Including the New WBRT-30-MM
}

\author{
DIRK RADES ${ }^{1}$, LENA SEHMISCH ${ }^{1}$, HEINKE C. HANSEN ${ }^{1}$, LIESA DZIGGEL $^{1}$, \\ STEFAN JANSSEN ${ }^{1,2}$ and STEVEN E. SCHILD ${ }^{3}$ \\ ${ }^{1}$ Department of Radiation Oncology, University of Lübeck, Lübeck, Germany; \\ ${ }^{2}$ Medical Practice for Radiotherapy and Radiation Oncology, Hannover, Germany; \\ ${ }^{3}$ Department of Radiation Oncology, Mayo Clinic, Scottsdale, AZ, U.S.A.
}

\begin{abstract}
Background/Aim: Diagnosis-specific scoring systems developed for predicting survival of patients with cerebral metastases from malignant melanoma $(M M)$ were evaluated. Patients and Methods: The new whole-brain radiotherapy (WBRT)-30-MM was created in homogeneously treated patients receiving 10×3 Gy of WBRT for cerebral metastases from MM. It consisted of three groups with significantly different 6-month survival rates of 0\% (3-5 points), 30\% (7 points) and 52\% (9 points) ( $p=0.001$ ). The WBRT-30-MM was compared to three other scores created for cerebral metastases from MM, including first updated DS-GPA classification, Dziggel-Score and Sehmisch-Score. Results: Positive predictive values (PPVs) for predicting death $\leq 6$ months after WBRT were 100\% (WBRT-30-MM), 77\% (DS-GPA), 69\% (Dziggel-Score) and 73\% (SehmischScore). PPVs for predicting survival $\geq 6$ months were $52 \%$, $38 \%, 63 \%$ and $75 \%$, respectively. Conclusion: WBRT-30$M M$ was the most accurate instrument for predicting death $\leq 6$ months. For predicting survival $\geq 6$ months, SehmischScore was most accurate, although all existing scorring systems appeared suboptimal for this purpose.
\end{abstract}

The majority of patients with cerebral metastases are treated with whole-brain radiotherapy (WBRT), either in combination with a local therapy such as neurosurgical resection or stereotactic radiosurgery, or as the only treatment (1). WBRT alone is commonly used for patients with multiple

Correspondence to: Prof. Dirk Rades, MD, Department of Radiation Oncology, University of Lübeck, Lübeck, Ratzeburger Allee 160, 23562 Lübeck, Germany. Tel: +49 45150045401, Fax: +49 45150045404, e-mail: dirk.rades@uksh.de

Key Words: Malignant melanoma, cerebral metastases, whole-brain radiotherapy, survival prognoses, diagnosis-specific scoring systems. cerebral metastases and patients in a poor general condition who may not benefit from resection or radiosurgery. WBRT is generally administered with five daily fractions per week. Common dose-fractionation regimens include 20 Gy in 5 fractions of $4 \mathrm{~Gy}, 30 \mathrm{~Gy}$ in 10 fractions of $3 \mathrm{~Gy}$ and $40 \mathrm{~Gy}$ in 20 fractions of $2 \mathrm{~Gy}$ delivered over one, two and four weeks, respectively (1). These regimens were reported to be similarly effective, particularly in patients with multiple cerebral metastases lesions $(2,3)$. When using higher dose per fraction of $\geq 3 \mathrm{~Gy}$, one should be aware that theses regimens bear a higher risk of subsequent neuro-cognitive decline (4). However, the development of neuro-cognitive deficits may take several weeks or even a few months, and, therefore, many patients with poor survival prognoses will die before experiencing significant neuro-cognitive deficits. Thus, 20 Gy in 5 fractions should be administered to patients with very limited survival times. These patients can benefit by spending less time receiving radiotherapy. In contrast, patients with relatively favorable survival prognoses live long enough to suffer post-WBRT neuro-cognitive decline (1). Therefore, doses per fraction of $<3$ Gy should be used for these patients. Moreover, in patients with very favorable survival prognoses, total WBRT-doses of $>30$ Gy were reported to lead to better intracerebral control and survival than doses of $30 \mathrm{~Gy}$ (5). It is clear that the WBRT-regimen should be adapted to the patients' survival prognoses. Therefore, scoring tools were developed to help physicians estimate an individual patient's prognosis. Such tools are also available for single tumor entities spreading to the brain and for different radiation techniques, to achieve an optimal individualization of treatment. Very few tools were created from data of patients with cerebral metastases from malignant melanoma (MM) selected to receive WBRT alone including the first updated diagnosis-specific graded prognostic assessment (DS-GPA) classification for MM from 2012, the Dziggel-Score from 2013 (developed in patients with less radiosensitive tumors including MM) and the Sehmisch-Score 
from 2017 (6-8). These tools were developed in heterogeneously treated patient cohorts, which may have resulted in biases. Therefore, we developed an additional scoring tool, the WBRT-30-MM that was developed in patients homogeneously treated with WBRT alone using 30 Gy in 10 fractions of $3 \mathrm{~Gy}$.

\section{Patients and Methods}

In a cohort of 51 patients uniformly treated with 10x3 Gy of WBRT alone for cerebral metastases from MM, eight characteristics (Table I) were investigated for potential influences on overall survival. These characteristics included the time from diagnosis of MM until WBRT ( $\leq 34$ versus $\geq 35$ months, median=34 months), pre-WBRT systemic treatment (no versus yes), controlled primary at the time of WBRT (no versus yes), extracerebral metastasis at the time of WBRT (no versus yes), age at the time of WBRT ( $\leq 62$ versus $\geq 63$ years, median=62 years), gender, Karnofsky performance score (KPS) ( $\leq 70$ versus $>70$, median $=70$ ) and the number of cerebral metastases ( $\leq 3$ (limited) versus $>3$ (multiple)). Characteristics that were significantly $(\mathrm{p}<0.05)$ associated with survival (calculated with the Kaplan-Meier method and the log-rank test) were used to design the WBRT-30-MM. The 6-months survival rates of the significant characteristics were divided by 10 to receive scoring points. Thereafter, the scoring points of each patient were summed up, and the patient scores were received. The patient scores formed the basis for the design of the prognostic groups.

The WBRT-30-MM was compared to three other scoring instruments designed for patients with cerebral metastases from $\mathrm{MM}$, i.e. the first updated diagnosis-specific graded prognostic assessment (DS-GPA) classification for MM, the Dziggel-Score (developed in patients with less radiosensitive tumors including MM receiving different WBRT regimens) and the Sehmisch-Score (developed in MM patients receiving different WBRT regimens with total doses $>30$ Gy) (6-8). The four instruments were compared with respect to positive predictive values (PPVs) to identify patients who will die within 6 months following WBRT and patients who will survive for 6 months or longer.

\section{Results}

A significantly positive influence on survival was found for a controlled primary tumour at the time of $\operatorname{WBRT}(p=0.002)$ and absence of extracerebral metastasis $(p=0.012)$ (Table II). The scoring points of the characteristics are summarized in Table III. Addition of the scoring points for each patient resulted in patient scores of 3, 5, 7 or 9 points with 6-month survival rates of $0 \%, 0 \%, 30 \%$ and $52 \%$, respectively. According to the patient scores, three groups were formed, 3-5 points $(n=7), 7$ points $(\mathrm{n}=23)$ and 9 points $(\mathrm{n}=21)$, with 6-month survival rates of $0 \%, 30 \%$ and $52 \%$, respectively ( $p=0.001$, Figure 1$)$.

The poor, intermediate and favorable prognoses groups of the WBRT-30-MM and the other instruments are given in Table IV. The PPVs of the poor prognoses groups to identify patients who will die within 6 months following WBRT were $100 \%$ (WBRT-30-MM), 77\% (first updated DS-GPA classification), 69\% (Dziggel-Score) and 73\% (Sehmisch-Score), respectively
Table I. Distribution of the investigated characteristics in the entire cohort.

\begin{tabular}{lc}
\hline Characteristic & Number of patients $(\%)$ \\
\hline Time diagnosis of MM until WBRT & \\
$\leq 34$ Months & $26(51)$ \\
$\geq 35$ Months & $25(49)$ \\
Pre-WBRT systemic treatment & \\
No & $22(43)$ \\
Yes & $29(57)$ \\
Controlled primary & \\
No & $7(14)$ \\
Yes & $44(86)$ \\
Extracerebral metastasis & \\
No & $10(20)$ \\
Yes & $41(80)$ \\
Age & \\
$\leq 62$ Years & $27(53)$ \\
$\geq 63$ Years & $24(47)$ \\
Gender & \\
Female & $15(29)$ \\
Male & $36(71)$ \\
Karnofsky performance score & \\
$\leq 70$ & $28(55)$ \\
$>70$ & $23(45)$ \\
Number of cerebral metastases & $18(35)$ \\
$\leq 3$ & $33(65)$ \\
$>3$ &
\end{tabular}

MM: Malignant melanoma; WBRT: whole-brain radiotherapy.

(6-8). The PPVs of the favorable prognoses groups to identify patients who will survive for 6 months or longer were 52\%, $38 \%, 63 \%$ and $75 \%$, respectively (6-8).

\section{Discussion}

Cerebral metastases occur in up to $30-40 \%$ of patients with malignant tumors (1). Due to improved treatments for primary tumors and loco-regionally recurrent disease, patients live longer and the number of patients experiencing distant metastatic disease including cerebral metastases is growing. These patients often require an individualized treatment regimen that should account for the remaining survival time. Also, selection of the appropriate WBRT regimen should consider the survival prognosis (1).

In a previous study of 416 patients with multiple cerebral metastases, WBRT with $30 \mathrm{~Gy}$ in 10 fractions was compared to WBRT with higher doses including $40 \mathrm{~Gy}$ in 20 fractions and $45 \mathrm{~Gy}$ in 15 fractions (3). The 6-month survival rates were $33 \%$ after $30 \mathrm{~Gy}$ and $29 \%$ after higher doses, respectively $(p=0.86)$, and the 6-month intracerebral control rates $39 \%$ and $41 \%$, respectively $(p=0.61)$. In a subsequent study of 442 patients that compared 30 Gy in 10 fractions to $20 \mathrm{~Gy}$ in 5 fractions, the 6-months survival rates were $27 \%$ and $24 \%$, respectively $(p=0.29)(2)$. Thus, patients with multiple lesions 
Table II. Survival rates after whole-brain radiotherapy.

\begin{tabular}{|c|c|c|c|c|}
\hline \multirow[t]{2}{*}{ Characteristic } & \multicolumn{3}{|c|}{ Survival rate $(\%)$} & \multirow[t]{2}{*}{$p$-Value } \\
\hline & $\begin{array}{c}\text { At } 3 \\
\text { months }\end{array}$ & $\begin{array}{c}\text { At } 6 \\
\text { months }\end{array}$ & $\begin{array}{l}\text { At } 12 \\
\text { months }\end{array}$ & \\
\hline \multirow{2}{*}{\multicolumn{5}{|c|}{$\begin{array}{l}\text { Time diagnosis of } \\
\text { MM until WBRT }\end{array}$}} \\
\hline & & & & \\
\hline$\leq 34$ Months & 50 & 31 & 9 & \multirow[t]{2}{*}{0.57} \\
\hline$\geq 35$ Months & 64 & 40 & 6 & \\
\hline \multicolumn{5}{|c|}{ Pre-WBRT systemic treatment } \\
\hline No & 50 & 32 & 5 & \multirow[t]{2}{*}{0.41} \\
\hline Yes & 62 & 38 & 9 & \\
\hline \multicolumn{5}{|c|}{ Controlled primary } \\
\hline No & 29 & 0 & 0 & \multirow[t]{2}{*}{0.002} \\
\hline Yes & 61 & 41 & 9 & \\
\hline \multicolumn{5}{|c|}{ Extracerebral metastasis } \\
\hline No & 50 & 50 & 13 & \multirow[t]{2}{*}{0.42} \\
\hline Yes & 59 & 32 & 6 & \\
\hline \multicolumn{5}{|l|}{ Age } \\
\hline$\leq 62$ Years & 67 & 37 & 8 & \multirow[t]{2}{*}{0.53} \\
\hline$\geq 63$ Years & 46 & 33 & 7 & \\
\hline \multicolumn{5}{|l|}{ Gender } \\
\hline Female & 53 & 40 & 0 & \multirow[t]{2}{*}{0.69} \\
\hline Male & 58 & 33 & 9 & \\
\hline \multicolumn{5}{|c|}{ Karnofsky performance score } \\
\hline$\leq 70$ & 36 & 25 & 4 & \multirow[t]{2}{*}{0.012} \\
\hline$>70$ & 83 & 48 & 11 & \\
\hline \multicolumn{5}{|c|}{ Number of cerebral metastases } \\
\hline$\leq 3$ & 72 & 33 & 6 & \multirow[t]{2}{*}{0.73} \\
\hline$>3$ & 48 & 36 & 8 & \\
\hline
\end{tabular}

MM: Malignant melanoma; WBRT: Whole-brain radiotherapy; Significant $p$-values are shown in bold.

Table III. Scoring points received from the 6-month survival rates of the characteristics that were significantly associated with survival.

\begin{tabular}{lcc}
\hline Characteristic & $\begin{array}{c}\text { 6-month survival } \\
\text { rate (\%) }\end{array}$ & $\begin{array}{c}\text { Scoring } \\
\text { points }\end{array}$ \\
\hline Controlled primary & & \\
No & 0 & 0 \\
Yes & 41 & 4 \\
Karnofsky performance score & & \\
$\leq 70$ & 25 & 3 \\
$>70$ & 48 & 5 \\
\hline
\end{tabular}

and limited survival prognoses appear candidates for WBRT with 20 Gy in 5 fractions. Due to findings from a randomized trial in 538 patients with cerebral metastases from non-small cell lung cancer, selected patients with very limited prognoses may even be considered for best supportive care (BSC) alone instead of BSC plus 20 Gy of WBRT (9).

For patients with cerebral metastases and very favorable survival prognoses, the situation is quite different. In these



Figure 1. Survival curves (Kaplan-Meier method) of the prognostic groups of the WBRT-30-MM.

patients, WBRT with total doses $>30$ Gy resulted in significantly improved 1-year overall survival (61\% vs. 50\%) and 1-year intracerebral control (44\% vs. 28\%) compared to $30 \mathrm{~Gy}$ in 10 fractions (5). Moreover, due to the longer survival, the risk of experiencing WBRT-related late morbidity including neuro-cognitive deficits is higher in this group of patients. Thus, doses per fraction $<3$ Gy should be used, and other options to reduce the risk of neuro-cognitive decline such as hippocampal sparing and memantine should be strongly considered $(4,10,11)$.

These data demonstrate that it is crucial to be able to judge a patient's survival time as accurately as possible to deliver the best possible treatment. Meanwhile, the treating radiation and medical oncologists can draw on several predictive tools helping them to estimate individual prognoses (12-20). In order to provide optimal individualization of the treatment regimen, separate tools were created for different primary tumors with a risk of intracerebral spread (12-18). One tumor type that requires particular attention is MM, since it is less radiosensitive than many other primary tumor types. This issue was already recognized before, and predictive tools for patients with cerebral metastases from MM were developed including the DS-GPA classification, the Dziggel-Score and the SehmischScore (6-8). All three previous scores were built from patients who received heterogeneous treatments. The treatments in the cohort used for creating DS-GPA were quite heterogeneous and included WBRT with different dose-fractionations including hyper-fractionation (two fractions per day), WBRT plus chemotherapy, WBRT plus a radio-sensitizer and WBRT plus a radiosurgery boost (6). Patients used for the Dziggel-Score received WBRT with different dose-fractionations and included also patients with cerebral metastases from colorectal cancer and renal cell carcinoma (7). The Sehmisch-Score was 
Table IV. Poor, intermediate and favorable prognoses groups of the WBRT-30-MM, first updated DS-GPA classification, Dziggel-Score and SehmischScore (6-8).

\begin{tabular}{|c|c|c|c|c|c|c|c|c|}
\hline \multirow[b]{2}{*}{$\begin{array}{l}\text { Survival } \\
\text { prognosis }\end{array}$} & \multicolumn{2}{|c|}{ WBRT-30-MM } & \multicolumn{2}{|c|}{ DS-GPA } & \multicolumn{2}{|c|}{ Dziggel-Score } & \multicolumn{2}{|c|}{ Sehmisch-Score } \\
\hline & $\begin{array}{c}\text { Scoring } \\
\text { points }\end{array}$ & $\begin{array}{l}\text { 6-month } \\
\text { survival }\end{array}$ & $\begin{array}{c}\text { Scoring } \\
\text { points }\end{array}$ & $\begin{array}{l}\text { 6-month } \\
\text { survival }\end{array}$ & $\begin{array}{c}\text { Scoring } \\
\text { points }\end{array}$ & $\begin{array}{l}\text { 6-month } \\
\text { survival }\end{array}$ & $\begin{array}{c}\text { Scoring } \\
\text { points }\end{array}$ & $\begin{array}{l}\text { 6-month } \\
\text { survival }\end{array}$ \\
\hline Poor & $3-5$ & $0 \%$ & $0-1$ & $23 \%$ & $5-8$ & $31 \%$ & 0 & $27 \%$ \\
\hline Intermediate & 7 & $30 \%$ & 2 & $53 \%$ & $9-11$ & $29 \%$ & 1 & $29 \%$ \\
\hline Favorable & 9 & $52 \%$ & $3-4$ & $38 \%$ & $12-14$ & $63 \%$ & 2 & $75 \%$ \\
\hline
\end{tabular}

developed in the least heterogeneously treated cohort of patients. All patients received WBRT alone with total doses $>30$ Gy, but still different dose-fractionation regimens (8). Thus, the creation of the previous tools may to lesser or greater extent had been impacted by hidden selection biases due to the different treatments the patients had received.

Therefore, we developed an additional tool, particularly for patients with cerebral metastases from MM, the WBRT-30-MM. All patients used for this tool received WBRT alone with $30 \mathrm{~Gy}$ in 10 fractions and, therefore, were more homogeneously treated than those patients used for the previous instruments. The WBRT-30-MM included three prognostic groups with 6month survival rates of $0 \%$ (3-5 points), 30\% (7 points) and $52 \%$ (9 points). The PPV to correctly predict death within 6 months after treatment was optimal with $100 \%$. This PPV was higher than the PPVs for the other scores that were $77 \%$ for the first updated DS-GPA classification, 69\% for the Dziggel-Score and $73 \%$ for the Sehmisch-Score, respectively (6-8). Thus, when aiming to identify patients who will likely die within 6 months after treatment, the WBRT-30-MM appears preferable. However, the PPV of the WBRT-30-MM to identify those patients who likely live for 6 months or longer was only $52 \%$. The PPV for the first updated DS-GPA classification was even worse (only 38\%), whereas the PPVs for the Dziggel-Score $(63 \%)$ and particularly for the Sehmisch-Score $(75 \%)$ were higher (6-8). Thus, when aiming to identify patients living for at least 6 months after treatment, the Sehmisch-Score appears to be the best option, although a PPV of $75 \%$ is not optimal. When using one of the predictive tools compared in this study, one should be aware that all scores were created from retrospective patient cohorts.

In summary, the new WBRT-30-MM was the most accurate instrument for predicting death $\leq 6$ months after WBRT. For predicting survival $\geq 6$ months, the SehmischScore was most accurate, although the PPVs of all four instruments appeared suboptimal.

\section{Conflicts of Interest}

On behalf of all Authors, the corresponding Author states that there is no conflict of interest related to this study.

\section{Authors' Contributions}

D.R., L.S., H.C.H., L.D., S.J. and S.E.S. participated in the design of the study. D.R., L.S., H.C.H., L.D. and S.J. provided data for the study. D.R. and S.E.S. performed the analyses. D.R., S.J. and S.E.S. performed the interpretation of the data. D.R. and S.E.S. drafted the manuscript, which has been reviewed and approved in its final form by all other Authors.

\section{References}

1 Tsao MN, Rades D, Wirth A, Lo SS, Danielson BL, Gaspar LE, Sperduto PW, Vogelbaum MA, Radawski JD, Wang JZ, Gillin MT, Mohideen N, Hahn CA and Chang EL: Radiotherapeutic and surgical management for newly diagnosed brain metastasis(es): An American Society for Radiation Oncology evidence-based guideline. Pract Radiat Oncol 2: 210-225, 2012. PMID: 25925626, DOI: 10.1016/j.prro.2011.12.004

2 Rades D, Kieckebusch S, Lohynska R, Veninga T, Stalpers LJ, Dunst $\mathrm{J}$ and Schild SE: Reduction of overall treatment time in patients irradiated for more than three brain metastases. Int $\mathrm{J}$ Radiat Oncol Biol Phys 69: 1509-1513, 2007. PMID: 17689033.

3 Rades D, Haatanen T, Schild SE and Dunst J: Dose escalation beyond 30 grays in 10 fractions for patients with multiple brain metastases. Cancer 110: 1345-1350, 2007. PMID: 17639588, DOI: $10.1002 /$ cncr.22906

4 DeAngelis LM, Delattre JY and Posner JB: Radiation-induced dementia in patients cured of brain metastases. Neurology 39: 789-796, 1989. PMID: 2725874.

5 Rades D, Panzner A, Dziggel L, Haatanen T, Lohynska R and Schild SE: Dose-escalation of whole-brain radiotherapy for brain metastasis in patients with a favorable survival prognosis. Cancer 118: 3852-3859, 2012. PMID: 22170514, DOI: $10.1002 /$ cncr.26680

6 Sperduto PW, Kased N, Roberge D, Xu Z, Shanley R, Luo X, Sneed PK, Chao ST, Weil RJ, Suh J, Bhatt A, Jensen AW, Brown PD, Shih HA, Kirkpatrick J, Gaspar LE, Fiveash JB, Chiang V, Knisely JP, Sperduto CM, Lin N and Mehta M: Summary report on the graded prognostic assessment: an accurate and facile diagnosis-specific tool to estimate survival for patients with brain metastases. J Clin Oncol 30: 419-425, 2012. PMID: 22203767, DOI: $10.1200 / \mathrm{JCO} .2011 .38 .0527$

7 Dziggel L, Segedin B, Podvrsnik NH, Oblak I, Schild SE and Rades D: A survival score for patients with brain metastases from less radiosensitive tumors treated with whole-brain radiotherapy alone. Strahlenther Onkol 190: 54-58, 2014. PMID: 23861153, DOI: 10.1007/s00066-013-0394-2 
8 Sehmisch L, Schild SE and Rades D: Development of a survival score for patients with cerebral metastases from melanoma. Anticancer Res 37: 249-252, 2017. PMID: 28011499, DOI: 10.21873/anticanres.11314

9 Mulvenna P, Nankivell M, Barton R, Faivre-Finn C, Wilson P, McColl E, Moore B, Brisbane I, Ardron D, Holt T, Morgan S, Lee C, Waite K, Bayman N, Pugh C, Sydes B, Stephens R, Parmar MK and Langley RE: Dexamethasone and supportive care with or without whole brain radiotherapy in treating patients with non-small cell lung cancer with brain metastases unsuitable for resection or stereotactic radiotherapy (QUARTZ): results from a phase 3 , non-inferiority, randomised trial. Lancet 388 : 2004-2014, 2016. PMID: 27604504, DOI: 10.1016/S01406736(16)30825-X

10 Gondi V, Pugh SL, Tome WA, Caine C, Corn B, Kanner A, Rowley H, Kundapur V, DeNittis A, Greenspoon JN, Konski AA, Bauman GS, Shah S, Shi W, Wendland M, Kachnic L and Mehta MP: Preservation of memory with conformal avoidance of the hippocampal neural stem-cell compartment during wholebrain radiotherapy for brain metastases (RTOG 0933): a phase II multi-institutional trial. J Clin Oncol 32: 3810-3816, 2014. PMID: 25349290, DOI: 10.1200/JCO.2014.57.2909

11 Brown PD, Pugh S, Laack N, Wefel JS, Khuntia D, Meyers C, Choucair A, Fox S, Suh JH, Roberge D, Kavadi V, Bentzen SM, Mehta MP, Watkins-Bruner D and Radiation Therapy Oncology Group (RTOG): Memantine for the prevention of cognitive dysfunction in patients receiving whole-brain radiotherapy: a randomized, double-blind, placebo-controlled trial. Neuro Oncol 15: 1429-1437, 2013. PMID: 23956241, DOI: 10.1093/neuonc/not114

12 Janssen S, Hansen HC, Schild SE and Rades D: An instrument for estimating the 6-month survival probability after whole-brain irradiation alone for cerebral metastases from gynecological cancer. Anticancer Res 38: 3753-3756, 2018. PMID: 29848738, DOI: 10.21873 /anticanres.12656

13 Dziggel L, Gebauer N, Bartscht T, Schild SE and Rades D: Performance status and number of metastatic extra-cerebral sites predict survival after radiotherapy of brain metastases from thyroid cancer. Anticancer Res 38: 2391-2394, 2018. PMID: 29599366, DOI: 10.21873/anticanres.12488
14 Rades D, Dziggel and Schild SE: A specific survival score for patients receiving local therapy for single brain metastasis from a gynecological malignancy. In Vivo 32: 825-828, 2018. PMID: 29936465, DOI: 10.21873/invivo.11314

15 Staackmann C, Janssen S, Schild SE and Rades D: A tool to predict the probability of intracerebral recurrence or new cerebral metastases after whole-brain irradiation in patients with head-and-neck cancer. Anticancer Res 38: 4199-4202, 2018. PMID: 2997055, DOI: 10.21873/anticanres.12714

16 Rades D, Dziggel L, Manig L, Janssen S, Khoa MT, Duong VN, Khiem VH and Schild SE: Predicting survival after whole-brain irradiation for cerebral metastases in patients with cancer of the bladder. In Vivo 32: 633-636, 2018. PMID: 29695570, DOI: 10.21873/invivo. 11285

17 Dziggel L, Schild SE, Veninga T, Bajrovic A and Rades D: Clinical factors asssociated with treatment outcomes following whole-brain irradiation in patients with prostate cancer. In Vivo 31: 35-38, 2017. PMID: 28064217, DOI: 10.21873/invivo.11021

18 Takamori S, Toyokawa G, Okamoto I, Takada K, Kinoshita F, Kozuma Y, Matsubara T, Haratake N, Akamine T, Mukae N, Hirai F, Tagawa T, Oda Y, Iwaki T, Iihara K, Nakanishi Y and Maehara Y: Clinical significance of PD-L1 expression in brain metastases from non-small cell lung cancer. Anticancer Res 38: 553-557, 2018. PMID: 29277823, DOI: 10.21873/anticanres.12258

19 Rades D, Blanck O, Khoa MT, Van Thai P, Hung NQ, Dziggel $\mathrm{L}$ and Schild SE: Validation of a survival score for patients receiving radiosurgery or fractionated stereotactic radiotherapy for 1 to 3 brain metastases. In Vivo 32: 381-384, 2018. PMID: 29475924, DOI: 10.21873/invivo.11249

20 Cha YJ, Jang WI, Kim MS, Yoo HJ, Paik EK, Jeong HK and Youn SM: Prediction of response to stereotactic radiosurgery for brain metastases using convolutional neural networks. Anticancer Res 38: 5437-5445, 2018. PMID: 30194200, DOI: 10.21873/anticanres. 12875

Received February 4, 2019

Revised February 18, 2019

Accepted February 19, 2019 